\title{
Determination of trace metals in air of Chittagong city-Bangladesh
}

\author{
Mohammed Jamaluddin Ahmed a,*, Mohammed Khorshed Ali a, Muzammel Hossain a, \\ Shajahan Siraj ${ }^{b}$ and Mohammed Aminul Ahsan ${ }^{b}$
}

\author{
a Laboratory of Analytical Chemistry, Department of Chemistry, University of Chittagong, Chittagong, 4331, Bangladesh \\ ${ }^{\mathrm{b}}$ Bangladesh Council of Scientific and Industrial Research Laboratories, Dhaka, 1205, Bangladesh \\ *Corresponding author at: Laboratory of Analytical Chemistry, Department of Chemistry, University of Chittagong, Chittagong, 4331, Bangladesh. \\ Tel.: +88.031.618236; Fax: +88.031.2606014.E-mail address:pmjahmed55@gmail.com (M.J. Ahmed).
}

\section{ARTICLE INFORMATION}

Received: 01 June 2012

Received in revised form: 17 August 2012

Accepted: 17 August 2012

Online: 31 December 2012

\section{KEYWORDS}

Air pollution

Trace metals

Air pollutants

Chittagong city

Particulate matter

Suspended particulate matter

\begin{abstract}
Air pollution problem is severe in the urban areas caused by both mobile as well as stationary sources. Mainly the two-stroke and diesel-run vehicles cause the severity of the problem by emitting highly contaminated exhausts. Considering severity of the problem, current study was undertaken to measure the air pollutants level in air of Chittagong city, Bangladesh. The heavy metals $\mathrm{Zn}, \mathrm{Pb}, \mathrm{Mn}, \mathrm{Cd}, \mathrm{Cu}$ and $\mathrm{Co}$ in suspended particulate matter (SPM) were determined at different locations of Chittagong city. The sampling locations were selected to reflect different influences from industrial and mobile sources in the highly populated center part of Chittagong city. Samplings were done during October and November 2008 from different areas of the metropolitan city of Chittagong city (Newmarket, Bahaddarhat, Nasirabad, General Electric Company (G.E.C.) Circle and Director's Office of Department of Environment, Bangladesh). High volume sampler was used for the determination of SPM and the different metal concentrations were measured by atomic absorption spectrophotometer (AAS). The average results of particulate matters and trace metals have been compared to national and international standards. The value of SPM in air of Chittagong city is higher than that of Threshold Limit Value (TLV) recommended by World Health Organization (WHO), Environmental Protection Agency (EPA), USA and Department of Environment (DoE), Bangladesh. The metal concentrations of ambient air collected at different locations in Chittagong city is exceeded the threshold limit values and as a result the air of Chittagong city is considered polluted. Therefore, it is suggested that Government of Bangladesh should take proper steps to control the air pollution of Chittagong city.
\end{abstract}

\section{Introduction}

Air is never found clean in nature, due to natural and manmade pollution. Gases such as $\mathrm{CO}, \mathrm{SO}_{2}, \mathrm{NO}_{2}$ and $\mathrm{H}_{2} \mathrm{~S}$ are continuously released into the atmosphere through natural activities and man-made pollutants-gases, mists and particulates, aerosols-resulting from the chemical and biological processes used by man. Air pollutants are present in the atmosphere in concentrations that disturb the dynamic equilibrium in the atmosphere and thereby affect man and his environment [1]. Air pollution is the introduction of chemicals, particulate matter, or biological materials that cause harm or discomfort to humans or other living organisms, or damages the natural environment, into the atmosphere [2]. Air pollution is a serious problem in many parts of the world. Limited resources, invested for the development of transport facilities, such as infrastructure and vehicles, coupled with the rapid rise in transport demand, existence of a huge number of nonmotorized vehicles on roads, lack of application of adequate and proper traffic management schemes are producing severe transport problems in almost all the urban areas of Bangladesh. Worsening situation of traffic congestion in the streets and sufferings of the inhabitants from vehicle emissions demand extensive research in this field. However, no detailed study concerning traffic congestion and pollution problems for urban areas of Bangladesh has yet been done [3].
The pollutants most often of concern with respect to transportation facilities are, carbon monoxide (CO), hydrocarbons $(\mathrm{HC})$, photochemical oxidants e.g., ozone $\left(\mathrm{O}_{3}\right)$, nitrogen oxides $\left(\mathrm{NO}_{\mathrm{x}}\right)$, particulate matter $(\mathrm{PM})$ and lead $(\mathrm{Pb})$. In spite of great improvements in most developed countries due to reduced use of leaded fuels, highway emissions of lead remain a persistent air quality problem [4]. Emission inventories of $\mathrm{NO}_{\mathrm{x}}$ and $\mathrm{SO}_{\mathrm{x}}$ have usually been made on national basis mainly for general administrative purposes and public information, systematic data published for the use of the scientific data is rather scarce. These oxides of nitrogen play a major role in the chemical reactions. An increase of nitrous oxide concentration in atmosphere may also lead to a decrease in the stratospheric ozone concentration, which may also affect surface temperature [5]. Other impacts from ozone include damaged vegetation and reduced crop yields [6]. Sulfur dioxide can cause long-term exposure such as respiratory illness, alter the lung's defense mechanisms, and aggravate existing cardiovascular disease. People with cardiovascular disease or chronic lung disease, as well as children and older adults, may be most susceptible to these effects [7].

Suspended particulate matter air pollution is an urban phenomenon, but in many areas of developed and developing countries, urban-rural differences in Particulate Matter 10 $\left(\mathrm{PM}_{10}\right)$ are small or even absent, indicating that $\mathrm{PM}$ exposure is widespread. Particulate matter has a direct effect on health as a result of respiration, because of the small size of the particles 
and the effect of heavy metals on biochemical mechanisms. Fine particles are more easily transported large distances and can stay in the air for a long time, depending on meteorological conditions and the size distribution [8]. It has been estimated that exposure to fine particulate matter in outdoor air leads to about 100000 deaths (and 725000 years of life lost) annually in Europe [9]. People with heart and lung disease, children and older adults are the most likely to be attacked by particle pollution exposure [10].

Chittagong city is located towards southeast of the capital city of Dhaka which is around $450 \mathrm{Km}$, Figure 1. It is situated within $22^{\circ}-14^{\prime}$ and $22^{\circ}-24^{\prime}-30^{\prime \prime} \mathrm{N}$ latitude and between $91^{\circ}-46^{\prime}$ and $91^{\circ}-53^{\prime} \mathrm{E}$ longitude and on the right bank of the river Karnafuli [11]. Chittagong is the second largest city and "Commercial Capital" of the country by this time. The main road network in the city goes toward the port area and northward toward the industrial areas. These roads are also heavily trafficked, with persistent traffic jams most of the day. Trucks transporting goods between the port and the industrial areas constitute a significant part of the traffic, and the combination of the hilly nature of the area, the stop and start mode of the congested traffic, and the age and heavy loading of most of the trucks causes large emissions of black diesel smoke. Brick kilns are an important source of building materials and pollution. Prior work in Dhaka, the capital city of Bangladesh, has suggested a major role for brick kilns in producing air pollution there [12].

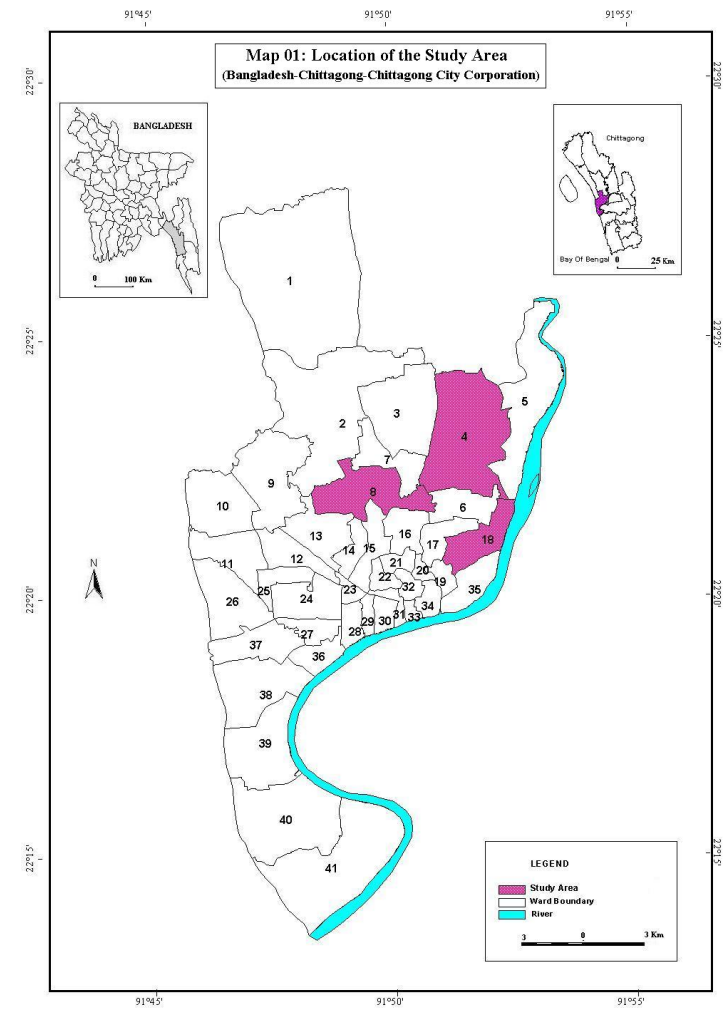

Figure 1. Map of Bangladesh showing the location of Chittagong. Insert color shows the location of study area.

The major sources contributing to the coarse PM fraction are soil dust including resuspended soil $(\sim 38 \%)$ and emissions from vehicles ( $\sim 26 \%$ ), which when combined account for $64 \%$ of the observed coarse mass. Alternatively, biomass burning, emissions from brick kilns ( 36\%), emissions from motor vehicle including road dust and compressed natural gas (CNG) vehicles ( 26\%), and Zn sources including two-stroke vehicles $(\sim 22 \%)$ are found to be the major contributors for fine PM.
Emissions from metal works also have significant contributions to fine PM [13]. The three wheeler vehicles were responsible for majority (around 60\%) of the air pollution in the city. Infect, these three wheelers were popular vehicles among the middle class and upper middle class people/societies of Chittagong city. By this time, Government of Bangladesh has imposed a ban on this two stroke three wheelers and invited new four stroke engine three wheeler CNG vehicles to replace two stroke vehicles. As a result of which, the city and the urban dwellers got rid of around $60 \%$ of air pollution by this time [14]. The $\mathrm{SO}_{2}$ and $\mathrm{NO}_{2}$ parameters of the Chittagong city is satisfactory but the value of SPM in the air of Chittagong city is greater than that of TLV value recommended by World Health Organization (WHO), Environmental Protection Agency, USA (EPA) and Department of Environment, Bangladesh (DoE) and thus it can be said that the air of Chittagong city is highly polluted. Motor vehicles, especially two-stroke engine vehicles are increasingly major sources of air pollution in Chittagong [15]. The level of urbanization in Bangladesh is low, but the rate of growth of urban population is very high and due to large total population the absolute number of population is also large. As a Divisional Headquarters, port city and commercial capital city, the rate of urbanization is also high in Chittagong metropolitan city. The impact of large influx of population in the city has been quite strong on the overall environmental situation in the city. The municipal authority should take a lead in organizing a concerted and coordinated effort with other governmental and non-governmental agencies in solving the problem of the city as soon as possible. The community people should also be mobilized in such efforts, because people's participation is very much fruitful in improving the environmental situation [16].

\section{Experimental}

There were five important sampling locations in Chittagong city had been chosen for the collection of the air sample. These were Newmarket, Bahaddarhat, Nasirabad, G.E.C Circle and Director's office of DOE. Sampling was done at the above sites using a high volume sampler. A high volume air sampler of Envirotech instrument model-APM 411 was used for the measurement of total suspended particulate matter (SPM). A high volume sampler was equipped with Whatmann glass micro fiber filters for the collection of samples. The high volume sampler instruments were set up on the roadside in all sampling locations. The height of the sampler was about six fit above from the ground surface. The all sampling operation was carried out from morning to evening for eight hours. Weather conditions were very sunny in all sampling locations. Finally all these air samples were taken into the laboratory instantly for the analysis.

The whole Whattmann glass micro fiber filter paper was divided into four small pieces and taken into a beaker. Concentrated $\mathrm{HNO}_{3}(3 \mathrm{~mL})$ and $\mathrm{HClO}_{4}(2 \mathrm{~mL})$ were added to it successively. Then it placed into hot plate for an hour. After that it was removed from the hot plate and kept for cooling. The full filter paper was digested by using this procedure. Therefore, for the complete digestion of one filter paper this procedure was carried out four times with very carefully. When the cooling operation was completed then $20 \mathrm{~mL}$ de-ionized water added to it. Then it was filtered to a $100 \mathrm{~mL}$ volumetric flask. The same procedure was followed for the remaining portions of that filter paper. After collection of the all four dissolution of the same filter paper to the $100 \mathrm{~mL}$ volumetric flask, it was about $80 \mathrm{~mL}$. The volumetric flask was up to the mark with de-ionized water and preserves it for the later analysis with highly caution. All the metal concentrations were determined by AA240FS fast sequential atomic absorption spectrophotometer (VARIAN) and GTA120 graphite tube atomizer, AA240Z Zeeman atomic absorption spectrophotometer. 


\subsection{Calibration curves for metal determination}

\subsubsection{Preparation of calibration curve for the determination oflead}

Stock standard lead solution (1000 mg/L) was prepared. For the preparation of $10.0 \mathrm{mg} / \mathrm{L}$ intermediate $\mathrm{Pb}$ standard, 5.0 $\mathrm{mL}$ stock Pb standard was taken in a $500 \mathrm{~mL}$ volumetric flask and diluted up to the mark with deionized water containing $10.0 \mathrm{~mL} \mathrm{HNO}_{3} .0 .5,1.0,2.0$ and $4.0 \mathrm{mg} / \mathrm{L}$ working standard was prepared from $10.0 \mathrm{mg} / \mathrm{L}$ intermediate standard for carrying out the analysis. $2.5 \mathrm{~mL}$ for $0.5,5.0 \mathrm{~mL}$ for $1.00,10 \mathrm{~mL}$ for 2.0 , $15 \mathrm{~mL}$ for 3.0 and $20 \mathrm{~mL}$ for $4.0 \mathrm{mg} / \mathrm{L}$ was taken from the 10.0 $\mathrm{mg} / \mathrm{L}$ intermediate standard solution in separate $50 \mathrm{~mL}$ volumetric flask. $1 \mathrm{~mL} \mathrm{HNO}_{3}$ acid was added to each and dilute up to the mark with deionized water. Working standard solution was prepared daily.

\subsubsection{Preparation of calibration curve for the determination of zinc}

Stock standard zinc solution (1000 mg/L) was prepared. For the preparation of $5.0 \mathrm{mg} / \mathrm{L}$ intermediate zinc standard, 2.5 $\mathrm{mL}$ stock zinc standard was taken in a $500 \mathrm{~mL}$ volumetric flask and diluted up to the mark with deionized water containing 10 mL $\mathrm{HNO}_{3} .0 .1,0.2,0.4$ and $0.8 \mathrm{mg} / \mathrm{L}$ working standard was prepared from $5.0 \mathrm{mg} / \mathrm{L}$ intermediate standard for carrying out the analysis. $1 \mathrm{~mL}$ for $0.1,2.0 \mathrm{~mL}$ for $0.2,4.0 \mathrm{~mL}$ for $0.4,6.0 \mathrm{~mL}$ for 0.6 and $8.0 \mathrm{~mL}$ for $0.8 \mathrm{mg} / \mathrm{L}$ was taken from the $5.0 \mathrm{mg} / \mathrm{L}$ intermediate standard solution in separate $50 \mathrm{~mL}$ volumetric flask. $1 \mathrm{~mL} \mathrm{HNO}_{3}$ acid was added to each and dilute up to the mark with deionized water. Working standard solution was prepared daily.

\subsubsection{Preparation of calibration curve for the determination of cadmium}

Stock standard cadmium solution (1000 mg/L) was prepared. For the preparation of $5.0 \mathrm{mg} / \mathrm{L}$ intermediate cadmium standard, $2.5 \mathrm{~mL}$ stock cadmium standard was taken in a $500 \mathrm{~mL}$ volumetric flask and diluted up to the mark with deionized water containing $10 \mathrm{~mL} \mathrm{HNO}_{3} .0 .5,1.0$, and $2.0 \mathrm{mg} / \mathrm{L}$ working standard was prepared from $5.0 \mathrm{mg} / \mathrm{L}$ intermediate standard for carrying out the analysis. $5 \mathrm{~mL}$ for $0.5,10.0 \mathrm{~mL}$ for 1.0, 15.0 for $1.5,20.0 \mathrm{~mL}$ for $2.0,25.0 \mathrm{~mL}$ for $2.5 \mathrm{mg} / \mathrm{L}$ was taken from the $5.0 \mathrm{mg} / \mathrm{L}$ intermediate standard solution in separate $50 \mathrm{~mL}$ volumetric flask. $1 \mathrm{~mL} \mathrm{HNO}$ acid was added to each and dilute up to the mark with deionized water. Working standard solution was prepared daily.

\subsubsection{Preparation of calibration curve for the determination of manganese}

Stock standard manganese solution (1000 mg/L) was prepared. For the preparation of $5.0 \mathrm{mg} / \mathrm{L}$ intermediate manganese standard, $2.5 \mathrm{~mL}$ stock manganese standard was taken in a $500 \mathrm{~mL}$ volumetric flask and diluted up to the mark with deionized water containing $10.0 \mathrm{~mL} \mathrm{HNO}_{3}$. 0.2, 0.5, 1.0, and $2.0 \mathrm{mg} / \mathrm{L}$ working standard was prepared from $5.0 \mathrm{mg} / \mathrm{L}$ intermediate standard for carrying out the analysis. $2.0 \mathrm{~mL}$ for $0.2,5.0 \mathrm{~mL}$ for $0.5,10.0 \mathrm{~mL}$ for $1.0,15.0 \mathrm{~mL}$ for 1.5 and $20.0 \mathrm{~mL}$ for $2.0 \mathrm{mg} / \mathrm{L}$ was taken from the $5.0 \mathrm{mg} / \mathrm{L}$ intermediate standard solution in separate $50 \mathrm{~mL}$ volumetric flask. $1 \mathrm{~mL}$ $\mathrm{HNO}_{3}$ acid was added to each and dilute up to the mark with deionized water. Working standard solution was prepared daily.

\subsubsection{Preparation of calibration curve for the determination of copper}

Stock standard copper solution (1000 mg/L) was prepared. For the preparation of $10.0 \mathrm{mg} / \mathrm{L}$ intermediate $\mathrm{Cu}$ standard, 5.0
$\mathrm{mL}$ stock $\mathrm{Cu}$ standard was taken in a $500 \mathrm{~mL}$ volumetric flask and diluted up to the mark with deionized water containing $10.0 \mathrm{~mL} \mathrm{HNO}_{3} .0 .5,1.0,2.0$ and $4.0 \mathrm{mg} / \mathrm{L}$ working standard was prepared from $10.0 \mathrm{mg} / \mathrm{L}$ intermediate standard for carrying out the analysis. $2.5 \mathrm{~mL}$ for $0.5,5.0 \mathrm{~mL}$ for $1.0,10.0 \mathrm{~mL}$ for 2.0 and $20.0 \mathrm{~mL}$ for $4.0 \mathrm{mg} / \mathrm{L}$ was taken from the $10.0 \mathrm{mg} / \mathrm{L}$ intermediate standard solution in separate $50 \mathrm{~mL}$ volumetric flask. $1 \mathrm{~mL} \mathrm{HNO}_{3}$ acid was added to each and dilute up to the mark with deionized water. Working standard solution was prepared daily.

\subsubsection{Preparation of calibration curve for the determination of cobalt}

Stock standard cobalt solution $(1000 \mathrm{mg} / \mathrm{L})$ was prepared. For the preparation of $10.0 \mathrm{mg} / \mathrm{L}$ intermediate Co standard, 5.0 $\mathrm{mL}$ stock Co standard was taken in a $500 \mathrm{~mL}$ volumetric flask and diluted up to the mark with deionized water containing 10 $\mathrm{mL} \mathrm{HNO}_{3} .0 .5,1.0$, and $2.0 \mathrm{mg} / \mathrm{L}$ working standard was prepared from $10.0 \mathrm{mg} / \mathrm{L}$ intermediate standard for carrying out the analysis. $2.5 \mathrm{~mL}$ for $0.5,5.0 \mathrm{~mL}$ for 1.0 , and $10.0 \mathrm{~mL}$ for $2.0 \mathrm{mg} / \mathrm{L}$ was taken from the $10.0 \mathrm{mg} / \mathrm{L}$ intermediate standard

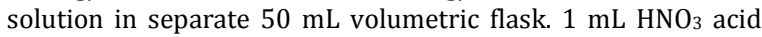
was added to each and dilute up to the mark with deionized water. Working standard solution was prepared daily.

\section{Results and discussions}

To cover the metropolitan area of Chittagong city, five different sampling stations (Newmarket, Bahaddarhat, General Electric Company (G.E.C.) Circle, Nasirabad and Director's Office of DOE) were selected for sample collection and the all observation continued from 9.00 AM to 5.00 PM. From these above locations Bahaddarhat was the highly traffic area and Director's office of DOE was the less traffic area. But other sampling locations were also more or less traffic. These samples were analyzed for particulate matter and trace metals ( $\mathrm{Zn}, \mathrm{Cu}, \mathrm{Co}, \mathrm{Mn}, \mathrm{Pb}$ and $\mathrm{Cd}$ ) concentrations. The study was conducted with direct support from the Department of Environment, Chittagong, using their assistance and lab facilities as required. In selecting the locations, initially opinion from the concerned authorities of the DOE were taken and then physical verification were made to overview the air status by examining associated phenomenon viz. intensity of the traffic congestion, smoke, fog, dust, fumes etc.

The mean SPM concentration of ambient air monitoring station varied from $658.21 \mu \mathrm{g} / \mathrm{m}^{3}$ (at station Director's office of DOE) to $2254.14 \mu \mathrm{g} / \mathrm{m}^{3}$ (at Bahaddarhat) with an overall mean concentration of $1602.01 \mu \mathrm{g} / \mathrm{m}^{3}$. The SPM concentration exceeded the permissible limit of $200 \mu \mathrm{g} / \mathrm{m}^{3}$ stipulated by DOE, Bangladesh, standard at all the locations. From the results of SPM concentration it is evident that vehicular traffic, a cluster of industries surrounding the Chittagong city area was mainly responsible for this. The concentration of suspended particulate matter in Chittagong city air has shown in Table 1. The other causes of higher value of SPM in Chittagong city air are incomplete combustion of fossil fuel of vehicles included car, jeep, bus, minibus, truck, human holler, microbus, four stroke engine driven vehicles like auto rickshaw, CNG etc. and motorbikes. Railway engines, industrial plants, power plants, brick fields, open burning incineration, solid waste disposal sites, road side dust particles, road diggings, constructions and other development activities are also contributing to the higher value of suspended particulate matter in air of Chittagong city.

The concentration of gaseous pollutants was found more at highly traffic areas. From the above results the highest concentration value of SPM was observed in highly traffic area at Bahaddarhat. The lowest concentration value was found in less traffic area at Director's Office of DOE. The average results of gaseous pollutants, particulate matters and trace metals have been compared to national and international standards. 
Table 1. The concentration of SPM, the average vehicles flow data (per hour) during the sampling period and the trace metal $(\mathrm{Zn}, \mathrm{Cu}$, $\mathrm{Co}$, Mn, $\mathrm{Pb}$ and $\mathrm{Cd}$ ) concentrations at different locations in Chittagong city.

\begin{tabular}{|c|c|c|c|c|c|c|c|c|c|c|c|}
\hline \multirow{2}{*}{$\begin{array}{l}\text { Sampling } \\
\text { date }\end{array}$} & \multirow[t]{2}{*}{ Sampling location } & \multirow{2}{*}{$\begin{array}{l}\text { Concentration of SPM } \\
\left(\mu \mathrm{g} / \mathrm{m}^{3}\right)\end{array}$} & \multicolumn{3}{|c|}{ Vehicles flow (per-hour) } & \multicolumn{6}{|c|}{ Metal concentration $\left(\mu \mathrm{g} / \mathrm{m}^{3}\right)$} \\
\hline & & & CNG (Auto) & Car & Bus & $\mathbf{P b}$ & Zn & Cd & Mn & $\mathrm{Cu}$ & Co \\
\hline \multirow{3}{*}{$\begin{array}{l}05.10 .08 \\
02.11 .08\end{array}$} & New market & 2490.95 & \multirow{3}{*}{636} & \multirow[t]{3}{*}{306} & \multirow[t]{3}{*}{168} & 0.53 & 221.37 & 0.021 & 0.813 & 2.04 & $<0.01$ \\
\hline & & 1515.96 & & & & 0.96 & 437.84 & 0.028 & 1.090 & 2.36 & $<0.01$ \\
\hline & Average & 2003.45 & & & & 0.74 & 329.60 & 0.024 & 0.951 & 2.20 & $<0.01$ \\
\hline \multirow{3}{*}{$\begin{array}{l}12.10 .08 \\
09.11 .08\end{array}$} & Bahaddarhat & 2147.40 & \multirow[t]{3}{*}{912} & \multirow[t]{3}{*}{426} & \multirow[t]{3}{*}{438} & 0.65 & 368.62 & 0.021 & 0.837 & 4.44 & $<0.01$ \\
\hline & & 2360.89 & & & & 0.19 & 338.11 & 0.015 & 0.555 & 3.46 & $<0.01$ \\
\hline & Average & 2254.14 & & & & 0.42 & 353.36 & 0.018 & 0.696 & 3.95 & $<0.01$ \\
\hline \multirow{3}{*}{$\begin{array}{l}18.10 .08 \\
15.11 .08\end{array}$} & Nasirabad & 1285.90 & \multirow[t]{3}{*}{532} & \multirow[t]{3}{*}{324} & \multirow[t]{3}{*}{211} & 0.46 & 412.76 & 0.018 & 1.553 & 4.36 & $<0.01$ \\
\hline & & 1678.85 & & & & 0.14 & 403.99 & 0.016 & 0.654 & 5.62 & $<0.01$ \\
\hline & Average & 1482.375 & & & & 0.30 & 408.34 & 0.017 & 1.103 & 4.99 & $<0.01$ \\
\hline \multirow{3}{*}{$\begin{array}{l}21.10 .08 \\
23.11 .08\end{array}$} & G.E.C. Circle & 1719.45 & \multirow[t]{3}{*}{655} & \multirow[t]{3}{*}{296} & \multirow[t]{3}{*}{311} & 0.15 & 412.80 & 0.017 & 0.721 & 8.88 & $<0.01$ \\
\hline & & 1504.39 & & & & 0.17 & 376.97 & 0.016 & 0.372 & 5.60 & $<0.01$ \\
\hline & Average & 1611.92 & & & & 0.16 & 394.88 & 0.017 & 0.546 & 14.48 & $<0.01$ \\
\hline \multirow{3}{*}{$\begin{array}{l}30.10 .08 \\
29.11 .08\end{array}$} & Director's office & 566.04 & \multirow[t]{3}{*}{294} & \multirow[t]{3}{*}{301} & \multirow[t]{3}{*}{252} & 0.44 & 393.34 & 0.019 & 0.744 & 8.92 & $<0.01$ \\
\hline & & 750.38 & & & & 0.66 & 437.43 & 0.023 & 0.747 & 16.46 & $<0.01$ \\
\hline & Average & 658.21 & & & & 0.55 & 415.39 & 0.021 & 0.745 & 12.69 & $<0.01$ \\
\hline
\end{tabular}

Table 2. Comparison of trace metal concentration of current study with other cities.

\begin{tabular}{|c|c|c|c|c|c|c|}
\hline \multirow{2}{*}{\multicolumn{2}{|c|}{ City }} & \multicolumn{4}{|c|}{ Trace metal concentration, $\mu \mathrm{g} / \mathrm{m}^{3}$} & \multirow{2}{*}{ Reference } \\
\hline & & $\mathrm{Cu}$ & Mn & $\mathbf{P b}$ & Cd & \\
\hline \multirow{4}{*}{\multicolumn{2}{|c|}{$\begin{array}{l}\text { Beijing, China } \\
\text { Islamabad, Pakistan } \\
\text { Vienna, Austria } \\
\text { Tehran, Iran }\end{array}$}} & - & 1.210 & 0.046 & 0.075 & Mori et al. [17] \\
\hline & & - & 0.059 & 0.214 & 0.015 & Shaheen et al. [18] \\
\hline & & 0.013 & - & 0.025 & - & Rostami et al. [19] \\
\hline & & - & 0.078 & 1.020 & 1.12 & Sohrabpour et al. [20] \\
\hline \multirow[t]{5}{*}{ Current study } & Bahaddarhat & 3.95 & 0.696 & 0.42 & 0.018 & \\
\hline & Newmarket & 2.20 & 0.951 & 0.745 & 0.0245 & \\
\hline & Nasirabad & 4.99 & 1.10 & 0.30 & 0.017 & \\
\hline & G.E.C. Circle & 14.48 & 0.54 & 0.16 & 0.0165 & \\
\hline & Director's Office & 12.69 & 0.74 & 0.55 & 0.021 & \\
\hline
\end{tabular}

The value of SPM in air of Chittagong city is eight times higher than that of TLV value $\left(500 \mu \mathrm{g} / \mathrm{m}^{3}\right)$ recommended by WHO and 12 times higher than the DOE standards $\left(200 \mu \mathrm{g} / \mathrm{m}^{3}\right)$. The average vehicles flow data (per hour) during the sampling period in different locations in Chittagong city has shown in Table 1.

Trace metals concentration in air were also determined in different places in Chittagong city in the different month like October and November 2008. Among these sampling locations some stations were highly traffic and some were less traffic. Road dust and vehicle smoke were the main source of trace metals in the air of Chittagong city. These values were increasing day by day due to the increasing of vehicles in the city area. The trace metal concentrations of different locations in Chittagong city were mentioned in Table 1 . Trace metals were determined by using atomic absorption spectrophotometer. The metal concentrations of ambient air that collected at different locations in Chittagong city is exceeded the threshold limit values and as a result the air of Chittagong city is polluted. Therefore, it is suggested that Government of Bangladesh should take proper steps to control the air pollution of Chittagong city and should be modified the existing national environmental policy.

\section{Conclusion}

Chittagong city is found to be one of the most polluted cities in Bangladesh. The study reveals that the status of air pollution was found to be very critical and it has taken the problems to a threatening dimension. In general, there is only a limited understanding of air quality in Chittagong. The rapid urban development that has occurred and is ongoing in Dhaka is also occurring in Chittagong and therefore Government has recognized that there is a real need to improve air quality management capacity in Chittagong.

The average results of trace metals have been compared to national and international standards. The copper concentration of current study was found very high in comparison with other results. The trace metal concentration of current study has been compared with different cities in the world in Table 2 . From these comparisons it was cleared that the values of current study somewhat more or less with other respective data.

\section{Acknowledgements}

We are especially indebted to the authorities, Department of Environment, Government of Bangladesh, Chittagong for their generous help during the collection of air samples and analyses. We are highly grateful to the authorities, Bangladesh Council of Scientific and Industrial Research Laboratories, Dhaka for their generous help and permit me for using atomic absorption spectrophotometer.

\section{References}

[1]. De, A. K. Environmental Chemistry, Fifth Edition, New Age International (P) Limited, New Delhi, 2000.

[2]. Wales, J. Wikipedia, 2009. 08/17/2012. http://www.en.wikipedia.org /wiki/Air pollution

[3]. Karim, M. M. Traffic pollution in Bangladesh \& Metropolitan Dhaka a Preliminary Investigation, 2009.

[4]. Karim, M. M.; Matsui, H.; Guensler, R. The 89th Annual Meeting of A \& WMA, Nashville, Tennessee, June 23-28, 1996.

[5]. Ming, H. Y. Environmental Toxicology. Second Edition, CRC Press LLC, USA, 2005, pp. 36-41.

[6]. Hare, S.; Cresswell, L.; Twig, R.; Buchdahal, J. Atmosphere, Climate \& Environmental Information Programme, Manchester Metropolitan University, Manchester, UK, 1999.

[7]. http://www.epa.gov/airquality/sulfurdioxide/health.html

[8]. Karim, M. M.; Matsui, H.; Transport and Environment, Elsevier Science Ltd. 1998, 3(2), 81-87.

[9]. WHO Regional Office for Europe, Health Aspects of Air Pollution http://www.euro.who.int/, Copenhagen, Denmark, 2003.

[10]. Brunkreef, B.; Holgate, S. T.; Air Pollution and Health, Lancet 2002 $360,1233-42$

[11]. Miah, S. National Encyclopedia of Bangladesh, Asiatic Society of Bangladesh, http://www.asiaticsociety.org.bd , Dhaka, Bangladesh, 3rd ed., 2009.

[12]. Begum, B. A.; Kim, E.; Biswas, S. K.; Hopke, P. K. Atmos. Environ. 2004 38, 3025-3038.

[13]. Begum, B. A.; Biswas, S. K.; Nasiruddin, M.; Hossain, A. M. S.; Hopke, P. K. Environ. Eng. Sci. 2009, 26(3), 679-689.

[14]. Hashemi, K. M. A. City Report of Chittagong, Asiatic Society of Bangladesh, http://www.asiaticsociety.org.bd, Dhaka, Bangladesh, $1^{\text {st }}$ ed., 2006.

[15]. Jamaluddin, A. M.; Khorshed, A. M. Int. J. Res. Chem. Environ. 2012 2(2), 178-187 
[16]. Majumder, A. K.; Hossain, M. E.; Islam, M. N.; Sarwar, M. I. Kathmandu Univ. J. Sci., Eng. Tech. 2007, 1(4) 1-11.

[17]. Mori, I. M.; Nishikawa, T. T.; Quan, H. Atmos. Environ. 2003, 37, 42634268.

[18]. Shaheen, N.; Shah, M. H.; Jaffar, M. Water Air Soil Poll. 2005, 164, 294302.

[19]. Rostami, S.; Sohrabpour, M.; Mirzaee, H.; Puxbaun, T. Environ. Int. 1999, 25, 969-981.

[20]. Sohrabpour, M.; Mirzaee, H.; Rostami, S.; Athari, M. Environ. Int. 1999, $25,75-83$. 